\title{
MARINE MINERALS AT THE NEW MILLENIUM
}

\section{PETER A. RONA}

A new view of marine minerals is emerging that links inorganic with organic processes and raises environmental issues. On the continental shelf recovery of common materials comprising sand and gravel for construction and seawater for desalinization will grow. Mineral sands containing $\mathrm{Au}, \mathrm{Pt}$, gemstones, $\mathrm{Sn}$ - or Ti-minerals will be targeted and traced seaward. Diamonds have developed into a mining industry offshore Namibia and South Africa with annual output near US\$1 billion. Deep seabed deposits comprising manganese nodules $(\mathrm{Mn}, \mathrm{Cu}, \mathrm{Ni}, \mathrm{Co}$; water depths 4000-6000 m), ferromanganese crusts ( $\mathrm{Mn}, \mathrm{Co}, \mathrm{Ni}, \mathrm{Pt}$; water depths 500-2500 m), and massive sulfide deposits ( $\mathrm{Cu}, \mathrm{Fe}, \mathrm{Zn}, \mathrm{Ag}, \mathrm{Au}$; water depths 2000-4000 m) will be mined. Ferromanganese crusts accumulate on rocky seabed elevations of seamounts, islands, and oceanic plateaus where they may be difficult to harvest. Massive sulfides are deposited from seafloor hot springs, which are sources both of the metals and of chemical energy utilized by heat-tolerant bacteria to manufacture their food at the base of a vent ecosystem linking inorganic with organic processes. The bacteria are sources of organic compounds for use in industrial processes and pharmaceuticals and may themselves relate to the base of the evolutionary tree of life. Mining of the metallic minerals and bioproducts produced at seafloor hot springs has the potential to benefit society and to threaten the environment. A theme of the 21 st century will be reconciling the conflict between societal benefits and environmental impacts of marine mining. 